\title{
A Survey on the Criteria for Measuring the Profitability of a Construction Organization
}

\author{
Aftab Hameed Memon \\ Department of Civil Engineering \\ Engineering Quaid-e-Awam University \\ of Engineering, Science \& Technology \\ Nawabshah, Pakistan \\ aftabm78@hotmail.com \\ Ammaar Noor Memon \\ Indus University \\ Karachi, Pakistan
}

\author{
Mohsin Ali Soomro \\ Department of Civil Engineering \\ Engineering Quaid-e-Awam University \\ of Engineering, Science \& Technology \\ Nawabshah, Pakistan
}

\author{
Nawab Ali Lakho \\ Department of Civil Engineering \\ Engineering Quaid-e-Awam University \\ of Engineering, Science \& Technology \\ Nawabshah, Pakistan
}

\author{
Muhammad Aslam Bhutto \\ Department of Civil Engineering \\ NED University \\ Karachi, Pakistan
}

\begin{abstract}
Any organization's performance depends on profitability which depends on several adopted criteria. The preference and level of adoption of these criteria varies, on different industries. This study focuses on investigating the criteria of profitability in the construction industry. This investigation involves a survey to seek the perception of the contractors involved in handling physical activities of construction works. The survey considered 63 questionnaire forms. Statistical analysis was performed to compute the frequency and the relative importance index. The results indicated that structural capital, lifetime values, capital structure and competitor actions are the top 4 criteria implemented in construction organizations to measure profitability.
\end{abstract}

Keywords-profitability; criteria of profitability; construction organization

\section{INTRODUCTION}

Profitability is considered a fundamental aspect for any enterprise. The same apply for organizations in the construction industry, which is a very fast growing industry, especially in developing countries such as Pakistan. Several researchers have identified various metrics of profitability measurement such as intellectual capital, relational capital, human capital and structural capital [1]. Another study showed that criteria for measuring profitability include unexpected product reliability failures, firm innovativeness, product reliability, warranty costs, unexpected product failure costs, moderating effect of industry innovativeness and firm return on assets (ROA) as the major metrics of profitability measurement [2]. Comprehensive review of literature resulted in finding 24 criteria for measuring organization profitability which are presented in Table I.

\section{METHODOLOGY}

Data was collected by conducting a survey amongst the representatives of contractor organizations handling construction projects in Pakistan. The survey was done using a structured questionnaire form designed based on literature review as discussed in Table I. For collected completed questionnaire forms, frequency was computed with SPSS. Using this, frequency, average index (AI) for each criterion was calculated using the following equation:

$$
R . I . I .=\frac{\sum_{1}^{5} a_{i} n_{i}}{5 N}
$$

where: $\mathrm{a}=$ constant expressing the weight assigned to each response, $\mathrm{n}=$ frequency of each response, $\mathrm{N}=$ total number of responses

TABLE I. CRITERIA FOR MEASURING PROFITABILITY

\begin{tabular}{|c|c|}
\hline Criterion & References \\
\hline Intellectual capital & {$[1,3-8]$} \\
\hline Relational capital & {$[1,9-13]$} \\
\hline Human capital & {$[1,9-13]$} \\
\hline Structural capital & {$[2,9-14]$} \\
\hline Unexpected product reliability failures & {$[2,14-17]$} \\
\hline Firm Innovativeness & {$[2,14,18-19]$} \\
\hline Product reliability & {$[2,15-16,18,20]$} \\
\hline Warranty costs & {$[2,17,21-23]$} \\
\hline Unexpected product failure costs & {$[2,21-22,24]$} \\
\hline $\begin{array}{l}\text { Moderating effect of industry } \\
\text { innovativeness }\end{array}$ & {$[2,14,19,20]$} \\
\hline Firm Return On Assets (ROA) & {$[2,17,21-22,25]$} \\
\hline Capital Structure & [26-28] \\
\hline Return on equity (ROE) & {$[26,29-31]$} \\
\hline Short term debt/total assets & {$[26,29-31]$} \\
\hline Long term debt/total assets & {$[26,29-31]$} \\
\hline Sales Growth & {$[26,29-31]$} \\
\hline Retention Resources & [32-34] \\
\hline Customer actions & [32-35] \\
\hline Competitor actions & [32-35] \\
\hline Industry type & {$[26,29-30,32]$} \\
\hline Annual revenue & {$[32-33,35]$} \\
\hline Firm size & {$[26,29-30,32]$} \\
\hline Cross-buying & [32-35] \\
\hline Lifetime values & [32-34] \\
\hline
\end{tabular}




\section{RESULTS AND DISCUSSION}

\section{A. Demographic Information of the Respondents}

Demographic information presents the characteristics of the participating respondents. During the survey, 100 questionnaire forms were distributing and 63 completed forms were received back and analyzed. The results of various characteristics of the respondents which include academic qualification and experience are presented in Table II.

TABLE II. DEMOGRAPHY OF THE RESPONDENTS

\begin{tabular}{|c|c|c|c|}
\hline $\begin{array}{c}\text { Metrics of } \\
\text { profitability }\end{array}$ & R.I.I. Value & \% age & Cumulative \%age \\
\hline \multicolumn{4}{|c|}{ Academic Qualification } \\
\hline Diploma & 18 & 28.6 & 28.6 \\
\hline B. E & 34 & 54.0 & 82.5 \\
\hline Masters & 8 & 12.7 & 95.2 \\
\hline B. Tech & 3 & 4.8 & 100 \\
\hline \multicolumn{5}{|c|}{ Experience (Years) } \\
\hline $\mathbf{0 - 5}$ & 23 & 36.5 & 36.5 \\
\hline $\mathbf{6 - 1 0}$ & 15 & 23.8 & 60.3 \\
\hline $\mathbf{1 1 - 1 5}$ & 9 & 14.3 & 74.6 \\
\hline$>\mathbf{1 5}$ & 16 & 25.4 & 100 \\
\hline
\end{tabular}

TABLE III. LEVEL OF IMPLEMENTATION

\begin{tabular}{|c|c|c|c|c|c|c|c|}
\hline \multirow{2}{*}{$\begin{array}{c}\text { Metrics of } \\
\text { profitability }\end{array}$} & \multicolumn{5}{|c|}{ Level of implementation } & \multirow{2}{*}{$\begin{array}{l}\text { R.I.I. } \\
\text { Value }\end{array}$} & \multirow{2}{*}{ Rank } \\
\hline & 1 & 2 & 3 & 4 & 5 & & \\
\hline Structural capital & 2 & 8 & 16 & 21 & 16 & 0.73 & 1 \\
\hline Lifetime values & 6 & 7 & 14 & 17 & 19 & 0.71 & 2 \\
\hline Capital Structure & 2 & 12 & 16 & 19 & 14 & 0.70 & 3 \\
\hline Competitor actions & 3 & 10 & 17 & 20 & 13 & 0.70 & 3 \\
\hline $\begin{array}{l}\text { Unexpected product } \\
\text { failure costs }\end{array}$ & 3 & 12 & 16 & 19 & 13 & 0.69 & 4 \\
\hline Return on equity (ROE) & 1 & 14 & 18 & 17 & 13 & 0.69 & 4 \\
\hline Industry type & 5 & 8 & 17 & 21 & 12 & 0.69 & 4 \\
\hline $\begin{array}{l}\text { Firm Return On } \\
\text { Assets (ROA) }\end{array}$ & 4 & 10 & 18 & 18 & 13 & 0.68 & 5 \\
\hline Firm size & 7 & 6 & 16 & 23 & 11 & 0.68 & 5 \\
\hline $\begin{array}{c}\text { Moderating effect of } \\
\text { industry innovativeness }\end{array}$ & 2 & 11 & 20 & 21 & 9 & 0.68 & 5 \\
\hline Firm Innovativeness & 3 & 12 & 17 & 22 & 9 & 0.67 & 6 \\
\hline Long term debt/total assets & 2 & 13 & 19 & 19 & 10 & 0.67 & 6 \\
\hline Sales Growth & 4 & 11 & 16 & 24 & 8 & 0.67 & 6 \\
\hline Annual revenue & 3 & 11 & 20 & 20 & 9 & 0.67 & 6 \\
\hline Product reliability & 6 & 10 & 12 & 28 & 7 & 0.66 & 7 \\
\hline Human capital & 3 & 12 & 22 & 15 & 11 & 0.66 & 7 \\
\hline Warranty costs & 4 & 8 & 22 & 23 & 6 & 0.66 & 7 \\
\hline Retention Resources & 7 & 7 & 22 & 15 & 12 & 0.66 & 7 \\
\hline Short term debt/total assets & 6 & 8 & 21 & 19 & 9 & 0.65 & 8 \\
\hline Customer actions & 7 & 12 & 14 & 17 & 13 & 0.65 & 8 \\
\hline Cross-buying & 3 & 15 & 19 & 15 & 11 & 0.65 & 8 \\
\hline Relational capital & 10 & 8 & 19 & 14 & 12 & 0.63 & 9 \\
\hline Intellectual capital & 10 & 11 & 20 & 13 & 9 & 0.60 & 10 \\
\hline $\begin{array}{l}\text { Unexpected product } \\
\text { reliability failures }\end{array}$ & 8 & 14 & 21 & 12 & 8 & 0.59 & 11 \\
\hline
\end{tabular}

\section{B. Level of Implementation}

The respondents were asked to rank the level of implementation for each criterion of profitability adopted by their organization. The results obtained are presented in Table
III. From Table III it can be perceived that 'structural capital' is the most commonly implementing metric in the construction projects of Pakistan

TABLE IV. LEVEL OF INFLUENCE

\begin{tabular}{|c|c|c|c|c|c|c|c|}
\hline \multirow{2}{*}{$\begin{array}{c}\text { Criteria of } \\
\text { profitability }\end{array}$} & \multicolumn{5}{|c|}{ Level of influence } & \multirow{2}{*}{$\begin{array}{l}\text { R.I.I. } \\
\text { Value }\end{array}$} & \multirow[t]{2}{*}{ Rank } \\
\hline & 1 & 2 & 3 & 4 & 5 & & \\
\hline Lifetime values & 5 & 9 & 11 & 14 & 24 & 0.74 & 1 \\
\hline Structural capital & 2 & 10 & 11 & 27 & 13 & 0.72 & 2 \\
\hline Human capital & 4 & 9 & 16 & 14 & 20 & 0.72 & 2 \\
\hline Firm size & 4 & 11 & 15 & 14 & 19 & 0.70 & 3 \\
\hline Industry type & 1 & 9 & 24 & 15 & 14 & 0.70 & 3 \\
\hline $\begin{array}{l}\text { Retention } \\
\text { Resources }\end{array}$ & 3 & 6 & 23 & 19 & 12 & 0.70 & 3 \\
\hline Annual revenue & 6 & 6 & 18 & 18 & 15 & 0.70 & 3 \\
\hline Product reliability & 4 & 7 & 20 & 20 & 12 & 0.69 & 4 \\
\hline Cross-buying & 5 & 8 & 17 & 22 & 11 & 0.68 & 5 \\
\hline $\begin{array}{l}\text { Long term debt/ } \\
\text { total assets }\end{array}$ & 4 & 12 & 17 & 15 & 15 & 0.68 & 5 \\
\hline Sales Growth & 3 & 9 & 24 & 17 & 10 & 0.67 & 6 \\
\hline Capital Structure & 4 & 14 & 16 & 15 & 14 & 0.67 & 6 \\
\hline Relational capital & 3 & 12 & 17 & 24 & 7 & 0.66 & 7 \\
\hline $\begin{array}{c}\text { Firm } \\
\text { innovativeness }\end{array}$ & 3 & 10 & 24 & 16 & 10 & 0.66 & 7 \\
\hline $\begin{array}{c}\text { Unexpected } \\
\text { product } \\
\text { reliability failures }\end{array}$ & 3 & 13 & 22 & 13 & 12 & 0.66 & 7 \\
\hline Customer actions & 2 & 15 & 18 & 19 & 9 & 0.66 & 7 \\
\hline Competitor actions & 6 & 10 & 18 & 18 & 11 & 0.66 & 7 \\
\hline $\begin{array}{l}\text { Short term debt/ } \\
\text { total assets }\end{array}$ & 6 & 11 & 18 & 16 & 12 & 0.65 & 8 \\
\hline $\begin{array}{c}\text { Firm Return On } \\
\text { Assets (ROA) }\end{array}$ & 1 & 16 & 21 & 16 & 9 & 0.65 & 8 \\
\hline Intellectual capital & 7 & 10 & 19 & 17 & 10 & 0.64 & 9 \\
\hline Warranty costs & 5 & 14 & 18 & 16 & 10 & 0.64 & 9 \\
\hline $\begin{array}{c}\text { Moderating effect } \\
\text { of industry } \\
\text { innovativeness }\end{array}$ & 5 & 10 & 29 & 8 & 11 & 0.63 & 10 \\
\hline $\begin{array}{l}\text { Return on equity } \\
\text { (ROE) }\end{array}$ & 4 & 15 & 21 & 13 & 10 & 0.63 & 10 \\
\hline $\begin{array}{l}\text { Unexpected } \\
\text { product failure } \\
\text { costs } \\
\end{array}$ & 8 & 6 & 26 & 19 & 4 & 0.62 & 11 \\
\hline
\end{tabular}

\section{Level of Influence of Criteria on Profitability}

Influence level of each criterion on profitability was measured according to the 5 point Likert scale and analysis results based on relative importance index values are shown in Table IV. From Table IV it is observed that the criterion 'lifetime values' cause extremely high influence on the company's profitability.

\section{CONCLUSION}

This study investigated the level of implementation and influence of various criteria used to measure profitability. Investigation involved a survey through structured questionnaires. Against 100 distributed questionnaire forms 63 were finally received and then statistically analyzed to calculate frequency and relative importance index values. The results indicated that 'structural capital', 'lifetime values', 'capital structure' and 'competitor actions' are the top 4 criteria implemented in construction organization to measure profitability. 


\section{REFERENCES}

[1] R. Sydler, S. Haefliger, R. Pruska "Measuring intellectual capital with financial figures: Can we predict firm profitability?", European Management Journal, Vol. 32, pp. 244- 259, 2014

[2] A. W. Mackelprang, M. Habermann, M. Swink, "How firm innovativeness and unexpected product reliability failures affect profitability", Journal of Operations Management Vo. 38, pp. 71-86, 2015

[3] N. Abu Bakar, H. Yusop, "Intellectual capital efficiency: Study on Malaysian banking sectors", Proceedings of Asia-Pacific Business Research Conference, Vol. 2, No. 3, pp. 1-9, 2012

[4] D. Andriessen, Making sense of intellectual capital: Designing a method for the valuation of intangibles, Routledge, 2004

[5] M. T. Bataineh, M. Al Zoabi, "The effect of intellectual capital on organizational competitive advantage: Jordanian Commercial Banks (Irbid district) an empirical study", International Bulletin of Business Administration, Vol. 10, No. 10, pp. 15-24, 2011

[6] M. d. R. Cabrita, N. Bontis, "Intellectual capital and business performance in the Portuguese banking industry", International Journal of Technology Management, Vol. 43, No. 1-3, pp. 212-237, 2008

[7] Y.-S. Chen, M.-J. Lin, C.-H. Chang, "The influence of intellectual capital on new product development performance - the manufacturing companies of Taiwan as an example", Total Quality Management \& Business Excellence, Vol. 17, No. 10, pp. 1323-1339, 2006

[8] S. Cohen, N. Kaimenakis, "Intellectual capital and corporate performance in knowledge intensive SMEs", The Learning Organization, Vol. 14, No. 3, pp. 241-262, 2007

[9] B. Marr, G. Schiuma, A. Neely, "The dynamics of value creation: Mapping your intellectual performance drivers", Journal of Intellectual Capital, Vol. 5, No. 2, pp. 312-325, 2004

[10] O. P. Pfeil, Earnings from intellectual capital as a driver of shareholder value, Haupt, 2004

[11] A. Riahi-Belkaoui, "Intellectual capital and firm performance of US multinational firms: A study of the resource-based and stakeholder views", Journal of Intellectual Capital, Vol. 4, No. 2, pp. 215-226, 2003

[12] G. Roos, A. Bainbridge, K. Jacobsen, "Intellectual capital analysis as a strategic tool”, Strategy \& Leadership, Vol. 29, No. 4, pp. 21-26, 2001

[13] S. Sudarsanam, G. Sorwar, B. Marr, "A finance perspective on intellectual capital. In B. Marr (Ed.), Perspectives on intellectual capital", Boston, MA: Butterworth-Heinemann, pp. 56-68, 2005

[14] T. Kim, W. G. Kim, S. S. Park, G. Lee, B. Jee, "Intellectual capital and business performance. What structural relationships do they have in upper-upscale hotels?", International Journal of Tourism Research, Vol. 14, pp. 391-408, 2012

[15] A. C. Brombacher, P. C. Sander, P. J. Sonnemans, J. L. Rouvroye, "Managing product reliability in business processes 'under pressure' Reliab", Reliability Engineering \& System Safety Vol. 88, No. 2, pp. $137-146,2005$

[16] J. A. Guajardo, M. A. Cohen, S.-H. Kim, S. Netessine, "Impact of performance-based contracting on product reliability: an empirical analysis", Management Science, Vol. 58, No. 5, pp. 961-979, 2012

[17] H.-Z. Huang, Z.-J. Liu, D. N. P. Murthy, "Optimal reliability, warranty and price for new products", IIE Transactions, Vol. 39, No. 8, pp. 819827,2007

[18] R. Adner, D. Levinthal, "Demand heterogeneity and technology evolution: implications for product and process innovation", Management Science, Vol. 47, No. 5, pp. 611-628, 2001

[19] G. Ahuja, C. Lampert, "Entrepreneurship in the large corporation: a longitudinal study of how established firms create breakthrough inventions", Strategic Management Journal, Vol. 22, No. 6-7, pp. 521543,2001

[20] S. Ahire, P. Dreyfus, "The impact of design management and process management on quality: an empirical investigation", Journal of Operations Management, Vol. 18, No. 5, pp. 549-575, 2000

[21] D. Cohen, M. N. Darrough, R. Huang, T. Zach, "Warranty reserve: contingent liability, information signal, or earnings management tool", Accounting Review, Vol. 86, No. 2, pp. 569-604, 2011

[22] J. Chu, P. K. Chintagunta, "An empirical test of warranty theories in the U.S. computer server and automobile markets", Journal of Marketing, Vol. 75, No. 2, pp. 75-92, 2011
[23] R. Karim, K. Suzuki, "Analysis of warranty claim data: a literature review”, Int. J. Qual. Reliab. Manage. Vol. 22, No. 7, pp. 667-686, 2005

[24] M. Hora, H. Bapuji, A. V. Roth, "Safety hazard and time to recall: the role of recall strategy, product defect type, and supply chain player in the US toy industry", Journal of Operations Management, Vol. 29, No. 7-8, pp. 766-777, 2011

[25] K. B. Hendricks, V. R. Singhal, "The effect of supply chain glitches on shareholder wealth", Journal of Operations Management, Vol. 21, No. 5, pp. 501-522, 2003

[26] M. A. Hamid, A. Abdullah, N. A. Kamaruzzaman, "Capital Structure and Profitability in Family and Non-Family Firms: Malaysian evidence", Procedia Economics and Finance, Vol. 31, pp. 44-55, 2015

[27] J. Abor, "The effect of capital structure on profitability: empirical analysis of listed firms in Ghana", Journal of Risk Finance. Vol. 6, No. 5 , pp. 438-45, 2005

[28] N. Ahmad, F. Abdul-Rahim, "Theoretical investigation on determinants of government-linked companies capital structure", Journal of Accounting, Finance and Economics, Vol. 3, No. 2, pp. 72-85, 2013

[29] N. Biger, N. V. Nguyen, Q. X. Hoang, "The determinants of capital structure: evidence from Vietnam", International Finance Review, Vol. 8, pp. 307-326, 2007

[30] A. Gill, N. Biger, C. Pai, S. Bhutani, "The determinants of capital structure in the service industry: evidence from United States", The Open Business Journal, Vol. 2, No. 1, pp. 48-53, 2009

[31] P. Nadaraja, A. H. Zulkafli, T. A. Masron, "Family ownership, firm's financial characteristics and capital structure: evidence from public listed companies in Malaysia”, Economia Seria Management, Vol. 14, No. 1, pp. $141-155,2011$

[32] W. Reinhartz, S. J. Thomas, V. Kumar, "Balancing Acquisition and Retention Resources to Maximize Customer Profitability", Journal of Marketing, Vol. 69, No. 1, pp. 63-79, 2005

[33] P. D. Berger, R. N. Bolton, D. Bowman, E. Briggs, V. Kumar, A Parasuraman, C. Terry, "Marketing Actions and the Value of Customer Assets", Journal of Service Research, Vol. 5, pp. 39-54, 2002

[34] R. Venkatesan, V. Kumar, "A Customer Lifetime Value Framework for Customer Selection and Resource Allocation Strategy", Journal of Marketing, Vol. 68, pp. 106-125, 2004

[35] R. T. Rust, K. T. Lemon, V. A. Zeithaml, "Return on Marketing: Using Customer Equity to Focus Marketing Strategy", Journal of Marketing, Vol. 68, pp. 109-127, 2004 